\title{
Defining competence profiles of different medical specialties with the requirement- tracking questionnaire - a pilot study to provide a framework for medial students' choice of postgraduate training
}

Elena Zelesniack', Viktor Oubaid ${ }^{2}$ and Sigrid Harendza ${ }^{1 *}$

\begin{abstract}
Background: The medical specialties are characterised by a great diversity in their daily work which requires different sets of competences. A requirement analysis would help to establish competence profiles of the different medical specialities. The aim of this pilot study was to define competence profiles for individual medical specialties. This could provide a framework as support for medical graduates who wish to choose a medical specialty for their postgraduate training.
\end{abstract}

Methods: In February 2020, physicians were invited via the State Chamber of Physicians' monthly journal to electronically fill out the requirement tracking (R-Track) questionnaire. It contains 63 aspects assigned to six areas of competence: "Mental abilities", "Sensory abilities", "Psychomotor and multitasking abilities", "Social interactive competences", "Motivation", and "Personality traits". The expression of the different aspects was assessed on a 5point Likert scale (1: "very low" to 5: "very high"). Sociodemographic data and information about the current workplace (hospital or practice) were also collected.

Results: In total, 195 practicing physicians from 19 different specialities followed the invitation by the State Chamber of Physicians to participate in this survey. For almost all medical specialties, the competence area "Motivation" reached rank 1. "Psychomotor and multitasking abilities" received high ranks among specialties performing surgical activities, while "Social interactive competences" and "Personality traits" were highly rated by specialties with an intense level of patient-physician-interaction. "Mental abilities" were only rated highly by radiologists (rank 2) and physiologists (rank 3) while "Sensory abilities" were generally rated very low with the expression (rank 4) for anaesthesiology and ENT.

(Continued on next page)

\footnotetext{
* Correspondence: harendza@uke.de

${ }^{1}$ III. Department of Internal Medicine, University Medical Center Hamburg-Eppendorf, Martinistr. 52, D-20246 Hamburg, Germany Full list of author information is available at the end of the article
}

C C The Author(s). 2021 Open Access This article is licensed under a Creative Commons Attribution 4.0 International License, which permits use, sharing, adaptation, distribution and reproduction in any medium or format, as long as you give appropriate credit to the original author(s) and the source, provide a link to the Creative Commons licence, and indicate if changes were made. The images or other third party material in this article are included in the article's Creative Commons licence, unless indicated otherwise in a credit line to the material. If material is not included in the article's Creative Commons licence and your intended use is not permitted by statutory regulation or exceeds the permitted use, you will need to obtain permission directly from the copyright holder. To view a copy of this licence, visit http://creativecommons.org/licenses/by/4.0/ The Creative Commons Public Domain Dedication waiver (http://creativecommons.org/publicdomain/zero/1.0/) applies to the data made available in this article, unless otherwise stated in a credit line to the data. 
(Continued from previous page)

Conclusions: In this pilot study, a first outline of competences profiles for 17 medical specialties were defined. The specific "Motivation" for a medical specialty seemed to play the greatest role for most specialties. This first specialty specific competence framework could provide a first insight into specific competences required by medical specialties and could serve medical graduate as a decision aid when looking for a medical specialty for their postgraduate training.

Keywords: Competence, Medical specialties, Requirement analysis, Postgraduate training

\section{Background}

The medical specialties are characterized by a great diversity of their daily work. They differ not only in their work settings, needed skills, duties, responsibilities, amount of patient contact, type of patients, and working hours but also in prestige, status, social expectations and income $[1,2]$. Taking this diversity into account, the decision making process and finally committing to a medical specialty for postgraduate medical education seems to be difficult for medical students $[3,4]$. The individual choice of a medical speciality for postgraduate training is usually a decision for a lifelong career and, therefore, a very important step in the career path of a physician [5, 6]. To understand, how medical students decide to choose their specialty for postgraduate training, is also important for health service providers, government agencies, policy makers, and medical educators, because it determines the future of primary and specialized care in a society [4]. Regarding the shortage of physicians in some medical specialties, e.g. general practitioners or surgeons [7-9], the connection between postgraduate students' specialty choice and physicians' work power needs to be examined to ensure a long-term structure and composition of the health workforce $[6,10,11]$.

The choice of a specialty for postgraduate training is a complex undertaking for medical graduates [12-14] and the career specialty decisions are influenced by many factors [15]. Prominent factors, which seem to have a high impact on specialty choice, include personality [1, 16], experiences in preclinical courses and clerkships $[17,18]$, role models $[19,20]$ or different gender preferences [21]. Other factors of relevance for the speciality selection are the amount of patient contact, geographic locations of practices, specialty-related income, and prestige including a growing interest in "controllable lifestyle" careers [15, 20-25]. From a more humorous perspective, certain characteristics have been attributed to medical specialities and have been collected in an algorithm for specialty decision making [26].

Finding a residency training position in a medical specialty works very differently according to a country's health and education system. While, e.g., in Germany graduates apply for a vacant position directly at a specific department of a hospital, The National Resident
Matching Program (NRMP) of the United States of America provides a specific matching system of residency candidates with certain residency programs. The institutions reserve the right to reject a candidate if a more suitable applicant arrives $[27,28]$. In order to make the right individual choice for a medical specialty, medical graduates need to reconcile their interests and values with their perception of the various specialist areas [6]. On the one hand, this concerns the graduates' interests, needs and strengths, and on the other hand, the working conditions and opportunities a specific speciality contains $[13,29]$. Because these are very different for the respective specialties, it is of central importance for the decision process to be familiar with the specific competences a certain specialty requires.

This pilot study aims to define competence profiles that reflect the specific requirements of different medical specialties. For this purpose, specialists from all medical specialties were invited to prioritize a set of competences for their specific daily work. These specialty specific competence profiles could provide multiple advantages: a guideline for medical graduates of what to expect in their favoured medical specialty and to evaluate their fit for a targeted specialty, an additional source of information for the design of postgraduate curricula and an orientation for personnel selection.

\section{Methods \\ Study design, participants and instrument}

To identify competence profiles of medical specialities, practicing physicians were invited to participate in this study via a link provided in Hamburger Ärzteblatt, a monthly journal in the German language, available in a print version for approximately 17,000 registered physicians in the state of Hamburg, Germany, and also available electronically for interested readers. The online survey of competences took place between February 1st and March 31st of 2020 on a voluntary basis. It contained the R-Track questionnaire, which was developed by Dr. Viktor Oubaid, psychologist at the German Aerospace Center. The questionnaire, originally designed to identify competence profiles of airline pilots, was adapted for health care professionals and other groups of professionals [30]. The design of R-Track is based on 
the Fleishman Job Analysis Survey (F-JAS) [31], which is a job analysis instrument of skills and abilities that are relevant for the accomplishment of certain occupational tasks or activities and can be used for all kind of professions [32].

The construction of the R-Track questionnaire is based on 6 areas of competence including a total of 63 questions: "Mental abilities" (14 questions, Cronbach's alpha: .86), "Sensory abilities (9 questions, Cronbach's alpha: .86), "Psychomotor and multitasking abilities" (2 questions, Cronbach's alpha: .59), "Personality traits" (12 questions, Cronbach's alpha: .78), "Motivation" (5 questions, Cronbach's alpha: .62), and "Social interactive competences" (21 questions, Cronbach's alpha: .87). All $\mathrm{R}$-Track items are provided in Supplement 1. The competences are assessed on a 5-point Likert scale (1: very low importance, 2: low importance, 3: moderate importance, 4: high importance, 5: very high importance) with respect to their importance in the current workplace. Socio-demographic data including sex and workplace (hospital or practice) were also collected. This study was performed in accordance with the Declaration of Helsinki and the Ethics Committee of the Chamber of Physicians, Hamburg, confirmed the innocuousness of the study with consented, anonymized, and voluntary participation (PV3649). All participants provided informed written consent for participation in this study.

\section{Data processing}

The R-Track questionnaire was presented in an online version. The assignments of items to these areas of competence were empirically proven by former data gained from medical requirement analysis [33]. Following Kleinmann et al. [32], only specialties with $n \geq 7$ participants were included in the analysis. Mean scores and standard deviations were calculated for all subgroups using SPSS Statistics 25. ANOVA procedures were used for mean score comparison of subgroups and post hoc analyses were carried out with LSD test. Differences were considered significant for $p$-values $<.05$.

\section{Results}

In total, 195 practicing physicians from 19 different medical specialties participated in the survey (anaesthesiology: $n=11$, dermatology: $n=10$, ENT: $n=13$, forensic medicine: $n=2$, general medicine: $n=11$, gynaecology: $n=7$, internal medicine: $n=20$, neurology: $\mathrm{n}$ $=11$, neurosurgery: $n=12$, occupational medicine: $n=$ 2, ophthalmology: $n=9$, orthopaedics / trauma surgery: $n=11$, paediatrics: $n=7$, physiology: $n=12$, psychiatry: $n=7$, psychosomatic medicine: $n=14$, radiology: $\mathrm{n}=9$, surgery: $n=14$, and urology: $n=13$ ). Their sociodemographic data are given in Table 1 . Occupational medicine $(n=2)$ and forensic medicine $(n=2)$ were excluded

Table 1 Sociodemographic data of participants

\begin{tabular}{|c|c|c|c|c|c|}
\hline \multirow[t]{2}{*}{ Medical specialty } & \multirow{2}{*}{$\begin{array}{l}\text { Participants } \\
\text { (n) }\end{array}$} & \multirow{2}{*}{$\begin{array}{l}\text { Sex (\%) } \\
\text { Female }\end{array}$} & \multirow[b]{2}{*}{ Male } & \multicolumn{2}{|c|}{ Workplace (\%) } \\
\hline & & & & Hospital & Practice \\
\hline Anaesthesiology & 11 & 45.5 & 54.5 & 90.9 & 9.1 \\
\hline Dermatology & 10 & 50.0 & 50.0 & 100.0 & 0.0 \\
\hline ENT & 13 & 30.8 & 69.2 & 92.3 & 7.7 \\
\hline Forensic medicine & 2 & 50.0 & 50.0 & 100.0 & 0.0 \\
\hline General Medicine & 11 & 90.9 & 9.1 & 45.5 & 54.5 \\
\hline Gynaecology & 7 & 57.1 & 42.9 & 85.7 & 14.3 \\
\hline Internal Medicine & 20 & 30.0 & 70.0 & 70.0 & 30.0 \\
\hline Neurology & 11 & 81.8 & 18.2 & 100.0 & 0.0 \\
\hline Neurosurgery & 12 & $25.0^{\mathrm{a}}$ & $66.7^{\mathrm{a}}$ & 91.7 & 8.3 \\
\hline Occupational medicine & 2 & 50.0 & 50.0 & 50.0 & 50.0 \\
\hline Ophthalmology & 9 & 55.6 & 44.4 & 66.7 & 33.3 \\
\hline Orthopaedics / Trauma Surgery & 11 & 18.2 & 81.8 & 63.6 & 36.4 \\
\hline Paediatrics & 7 & 28.6 & 71.4 & 71.4 & 28.6 \\
\hline Physiology & 12 & 16.7 & 83.3 & 100.0 & 0.0 \\
\hline Psychiatry & 7 & 57.1 & 42.9 & 57.1 & 42.9 \\
\hline Psychosomatic Medicine & 14 & 64.3 & 35.7 & 100.0 & 0.0 \\
\hline Radiology & 9 & 0.0 & 100.0 & 100.0 & 0.0 \\
\hline Surgery & 14 & 50.0 & 50.0 & 100.0 & 0.0 \\
\hline Urology & 13 & 23.1 & 76.9 & 69.2 & 30.8 \\
\hline
\end{tabular}

$8.3 \%$ gave no gender information 
from the data analysis due to the low number of participants.

The highest mean score (rank 1) was reached in the competence area "Motivation" by all participating medical specialties included in the data analysis except for ophthalmology (rank 1: "Psychomotor and multitasking abilities") and psychiatry (rank 1: "Personality traits") where "Motivation" reached rank 2 and 3, respectively (Table 2). The individual item with the highest score in the competence area "Motivation" was "Expertise", the result of invested time and effort, for 14 specialities. "Personality traits" reached rank 2 by seven specialties and rank 3 by seven other specialties. The competence area "Psychomotor and multitasking abilities" received rank 2 by anaesthesiology, dermatology, ENT, neurosurgery, orthopaedics/trauma surgery, surgery, and urology. "Social interactive competences" reached rank 2 or 3, respectively, by ENT, general medicine, gynaecology, internal medicine, neurology, paediatrics, psychiatry, psychosomatic medicine, and radiology. The competence area "Mental abilities" was only ranked highly by radiologists and physiologists (rank 2 and 3, respectively). "Sensory abilities" reached ranks below 3 by all specialties with its highest rank being 4 only for anaesthesiology and ENT. ANOVA analyses revealed significant differences for medical specialties for all competencies except "Personality traits" with the largest differences in "Psychomotor and multitasking abilities" (F $(16,174)=$ $10.45 ; p<.001)$, where specialties with a surgical focus had higher scores.

Table 2 Means and ranks of the six competence areas per specialty

\begin{tabular}{|c|c|c|c|c|c|c|}
\hline \multirow[b]{2}{*}{ Medical specialty } & \multicolumn{6}{|c|}{ Competence area } \\
\hline & $\begin{array}{c}\text { Mental } \\
\text { abilities } \\
\text { MW } \pm \text { SD } \\
\text { (rank) }\end{array}$ & $\begin{array}{c}\text { Sensory } \\
\text { abilities } \\
\text { MW } \pm \text { SD } \\
\text { (rank) }\end{array}$ & $\begin{array}{c}\text { Psychomotor \& } \\
\text { multitasking abilities } \\
\text { MW } \pm \text { SD } \\
\text { (rank) }\end{array}$ & $\begin{array}{c}\text { Motivation } \\
\text { MW } \pm \text { SD } \\
\quad(\text { rank) }\end{array}$ & $\begin{array}{l}\text { Social interactive } \\
\text { competences } \\
\text { MW } \pm \text { SD } \\
\text { (rank) }\end{array}$ & $\begin{array}{c}\text { Personality } \\
\text { traits } \\
\text { MW } \pm \text { SD } \\
\text { (rank) }\end{array}$ \\
\hline $\begin{array}{l}\text { Anaesthesiology } \\
n=11\end{array}$ & $\begin{array}{c}3.63 \pm 0.98 \\
(6)\end{array}$ & $\begin{array}{c}3.91 \pm 0.90 \\
(4)\end{array}$ & $\begin{array}{c}4.09 \pm 1.04 \\
(2)\end{array}$ & $\begin{array}{c}4.38 \pm 0.43 \\
(1)\end{array}$ & $\begin{array}{c}3.79 \pm 0.60 \\
(5)\end{array}$ & $\begin{array}{c}4.01 \pm 0.44 \\
(3)\end{array}$ \\
\hline $\begin{array}{l}\text { Dermatology } \\
n=10\end{array}$ & $3.83 \pm 0.45$ & $\begin{array}{c}3.75 \pm 0.42 \\
(6)\end{array}$ & $4.30 \pm 0.48$ & $4.52 \pm 0.53$ & $3.91 \pm 0.36$ & $\begin{array}{c}3.92 \pm 0.51 \\
\text { (3) }\end{array}$ \\
\hline $\begin{array}{l}\text { ENT } \\
n=13\end{array}$ & $\begin{array}{c}3.79 \pm 0.64 \\
(6)\end{array}$ & $\begin{array}{c}3.90 \pm 0.67 \\
(4)\end{array}$ & $4.42 \pm 0.81$ & $\begin{array}{c}4.55 \pm 0.34 \\
(1)\end{array}$ & $\begin{array}{c}4.06 \pm 0.46 \\
\text { (3) }\end{array}$ & $\begin{array}{c}3.88 \pm 0.65 \\
(5)\end{array}$ \\
\hline $\begin{array}{l}\text { General Medicine } \\
n=11\end{array}$ & $\begin{array}{c}3.32 \pm 0.28 \\
(4)\end{array}$ & $\begin{array}{c}2.93 \pm 0.55 \\
(6)\end{array}$ & $\begin{array}{c}3.05 \pm 0.47 \\
(5)\end{array}$ & $\begin{array}{c}3.93 \pm 0.45 \\
\text { (1) }\end{array}$ & $\begin{array}{c}3.66 \pm 0.32 \\
\text { (3) }\end{array}$ & $\begin{array}{c}3.85 \pm 0.49 \\
\text { (2) }\end{array}$ \\
\hline $\begin{array}{l}\text { Gynaecology } \\
n=7\end{array}$ & $\begin{array}{c}3.60 \pm 0.84 \\
(4)\end{array}$ & $\begin{array}{c}3.38 \pm 0.97 \\
(6)\end{array}$ & $\begin{array}{c}3.50 \pm 0.91 \\
(5)\end{array}$ & $\begin{array}{c}4.06 \pm 0.41 \\
\text { (1) }\end{array}$ & $3.67 \pm 0.36$ & $\begin{array}{c}3.75 \pm 0.38 \\
\text { (2) }\end{array}$ \\
\hline $\begin{array}{l}\text { Internal Medicine } \\
n=20\end{array}$ & $\begin{array}{c}3.76 \pm 0.59 \\
(4)\end{array}$ & $\begin{array}{c}3.43 \pm 0.70 \\
(5)\end{array}$ & $\begin{array}{c}3.38 \pm 0.72 \\
(6)\end{array}$ & $\begin{array}{c}4.36 \pm 0.39 \\
(1)\end{array}$ & $\begin{array}{c}3.91 \pm 0.41 \\
(2)\end{array}$ & $\begin{array}{c}3.89 \pm 0.42 \\
(3)\end{array}$ \\
\hline $\begin{array}{l}\text { Neurology } \\
n=11\end{array}$ & $\begin{array}{c}3.57 \pm 0.49 \\
(4)\end{array}$ & $\begin{array}{c}3.07 \pm 0.47 \\
(6)\end{array}$ & $\begin{array}{c}3.55 \pm 0.47 \\
(5)\end{array}$ & $\begin{array}{c}4.40 \pm 0.45 \\
(1)\end{array}$ & $3.61 \pm 0.43$ & $\begin{array}{c}3.73 \pm 0.34 \\
\text { (2) }\end{array}$ \\
\hline $\begin{array}{l}\text { Neurosurgery } \\
n=12\end{array}$ & $\begin{array}{c}3.86 \pm 0.47 \\
(6)\end{array}$ & $\begin{array}{c}3.96 \pm 0.55 \\
(5)\end{array}$ & $\begin{array}{c}4.58 \pm 0.42 \\
(2)\end{array}$ & $\begin{array}{c}4.58 \pm 0.39 \\
(1)\end{array}$ & $\begin{array}{c}3.98 \pm 0.49 \\
(4)\end{array}$ & $\begin{array}{c}4.05 \pm 0.46 \\
\text { (3) }\end{array}$ \\
\hline $\begin{array}{l}\text { Ophthalmology } \\
n=9\end{array}$ & $\begin{array}{c}3.55 \pm 0.51 \\
(5)\end{array}$ & $3.51 \pm 0.38$ & $\begin{array}{c}4.39 \pm 0.55 \\
(1)\end{array}$ & $\begin{array}{c}4.31 \pm 0.46 \\
(2)\end{array}$ & $\begin{array}{c}3.69 \pm 0.53 \\
(4)\end{array}$ & $\begin{array}{c}3.83 \pm 0.40 \\
\text { (3) }\end{array}$ \\
\hline $\begin{array}{l}\text { Orthopaedics / Trauma Surgery } \\
n=11\end{array}$ & $\begin{array}{c}3.56 \pm 0 \\
(5)\end{array}$ & $\begin{array}{c}3.28 \pm 0.74 \\
(6)\end{array}$ & $\begin{array}{c}3.86 \pm 0.67 \\
(3)\end{array}$ & $\begin{array}{c}4.55 \pm 0.37 \\
(1)\end{array}$ & $\begin{array}{c}3.83 \pm 0.39 \\
(4)\end{array}$ & $\begin{array}{c}4.00 \pm 0.45 \\
(2)\end{array}$ \\
\hline $\begin{array}{l}\text { Paediatrics } \\
n=7\end{array}$ & $\begin{array}{c}3.37 \pm 0.38 \\
(4)\end{array}$ & $\begin{array}{c}3.27 \pm 0.57 \\
(6)\end{array}$ & $\begin{array}{l}3.36 \pm 0.85 \\
(5)\end{array}$ & $\begin{array}{c}4.20 \pm 0.58 \\
(1)\end{array}$ & $\begin{array}{c}3.79 \pm 0.38 \\
(3)\end{array}$ & $\begin{array}{c}3.92 \pm 0.54 \\
\quad(2)\end{array}$ \\
\hline $\begin{array}{l}\text { Physiology } \\
n=12\end{array}$ & $\begin{array}{c}3.71 \pm 0.38 \\
(3)\end{array}$ & $\begin{array}{c}2.85 \pm 0.69 \\
(6)\end{array}$ & $\begin{array}{c}3.13 \pm 1.19 \\
(5)\end{array}$ & $\begin{array}{c}4.33 \pm 0.21 \\
(1)\end{array}$ & $\begin{array}{c}3.38 \pm 0.54 \\
(4)\end{array}$ & $\begin{array}{c}3.73 \pm 0.40 \\
\quad(2)\end{array}$ \\
\hline $\begin{array}{l}\text { Psychiatry } \\
n=7\end{array}$ & $\begin{array}{c}3.62 \pm 0.66 \\
(4)\end{array}$ & $\begin{array}{l}2.98 \pm 0.88 \\
(5)\end{array}$ & $\begin{array}{c}2.57 \pm 1.10 \\
(6)\end{array}$ & $\begin{array}{c}3.74 \pm 0.46 \\
(3)\end{array}$ & $\begin{array}{c}3.74 \pm 0.41 \\
(2)\end{array}$ & $\begin{array}{c}3.99 \pm 0.35 \\
\quad(1)\end{array}$ \\
\hline $\begin{array}{l}\text { Psychosomatic Medicine } \\
n=14\end{array}$ & $\begin{array}{c}3.50 \pm 0.46 \\
(4)\end{array}$ & $\begin{array}{c}2.99 \pm 0.55 \\
(5)\end{array}$ & $\begin{array}{c}2.11 \pm 0.74 \\
(6)\end{array}$ & $\begin{array}{c}4.23 \pm 0.51 \\
(1)\end{array}$ & $\begin{array}{c}4.10 \pm 0.21 \\
(3)\end{array}$ & $\begin{array}{l}4.12 \pm 0.40 \\
(2)\end{array}$ \\
\hline $\begin{array}{l}\text { Radiology } \\
n=9\end{array}$ & $\begin{array}{c}4.50 \pm 0.53 \\
(2)\end{array}$ & $\begin{array}{c}4.06 \pm 0.50 \\
(5)\end{array}$ & $\begin{array}{c}3.56 \pm 0.77 \\
(6)\end{array}$ & $\begin{array}{c}4.73 \pm 0.28 \\
(1)\end{array}$ & $\begin{array}{c}4.22 \pm 0.59 \\
\text { (3) }\end{array}$ & $\begin{array}{c}4.17 \pm 0.51 \\
(4)\end{array}$ \\
\hline $\begin{array}{l}\text { Surgery } \\
n=14\end{array}$ & $\begin{array}{c}3.65 \pm 0.57 \\
(5)\end{array}$ & $\begin{array}{c}3.64 \pm 0.46 \\
(6)\end{array}$ & $\begin{array}{c}4.43 \pm 0.55 \\
\text { (2) }\end{array}$ & $\begin{array}{c}4.54 \pm 0.44 \\
\text { (1) }\end{array}$ & $\begin{array}{c}3.85 \pm 0.50 \\
(4)\end{array}$ & $\begin{array}{c}4.14 \pm 0.47 \\
\text { (3) }\end{array}$ \\
\hline $\begin{array}{l}\text { Urology } \\
n=13\end{array}$ & $\begin{array}{c}3.62 \pm 0.53 \\
(5)\end{array}$ & $\begin{array}{c}3.54 \pm 0.73 \\
(6)\end{array}$ & $\begin{array}{c}4.12 \pm 0.58 \\
(2)\end{array}$ & $\begin{array}{c}4.28 \pm 0.44 \\
\text { (1) }\end{array}$ & $\begin{array}{c}3.73 \pm 0.47 \\
(4)\end{array}$ & $\begin{array}{c}4.00 \pm 0.52 \\
\text { (3) }\end{array}$ \\
\hline
\end{tabular}




\section{Discussion}

Almost all medical specialties participating in our survey regarded "Motivation" as the most important competence area for their specialty with "Expertise" being the highest ranked individual item within this category for most specialties. This is an interesting finding, since the everyday work of medical experts is very different for specialties like, e.g. ophthalmology or psychosomatic medicine. However, this finding is in line with selfefficacy - a positive conviction of a person's ability to successfully perform a certain action - being an essential aspect for motivation [34]. Enthusiasm for and commitment to a certain specialty have been shown to be among the most important aspects for junior doctors' future specialty choice [35] and seem to be a continuing driving force for medical experts' work in most specialties according to our findings. Nurturing medical students' interest in surgery and providing motivating experiences in the surgical field during undergraduate training, for instance, increased medical graduates' wish to choose surgery as specialty for their postgraduate education [36]. This could be a useful recruiting strategy for other specialties as well.

We also discovered interesting differences between the specialties with respect to the other five competence areas. As expected, "Psychomotor and multitasking abilities" were highly rated by physicians from all specialties that are involved in different kinds of surgical procedures. Most of these specialties require specific skills training, which begins during undergraduate medical education [37] and continues during postgraduate education where more specific psychomotor skills are needed depending on the specialty [38, 39]. Historically, surgeons have always been physicians who are involved with motorically challenging treatments and the divergence of surgery and medicine is still increasing [40]. Physicians from specialties where more narrative competences are required [41], e.g. internal medicine, general medicine or paediatrics, rated the competence areas "Social interactive competences" and "Personality traits" highly. For internists, a broad spectrum of interpersonal skills and communicative competences has been defined [42]. General medicine is associated with a high level of uncertainty [43], which requires a strong focus on the empathic interaction between physician and patient. For paediatricians, empathetic involvement with the patients' parents is of great importance because of the often heterogeneous and non-specific symptoms of the patients [44]. For physicians working in psychiatry and psychosomatic medicine, empathetic understanding plays an important role for their therapeutic relationships with the patients [45]. "Emotional stability" and "Openness to other people/cultures" were rated as the most important aspects in the competence areas "Social interactive competences" and "Personality traits" by most of these specialties.

The competence area "Mental abilities" was only rated highly by radiologists and physiologists. This could be due to the fact that radiologists spend a lot of time on the reconstruction of two- or three-dimensional imaging $[46,47]$ and physiologists' field of work focuses on abstract thinking [48]. Medical graduates who wish to choose either specialty for their postgraduate training need to be aware that - besides motivation - their specific focus and interest should lie on mental abilities required as specifically prominent area of competence for radiology and physiology. "Sensory abilities" were rated relatively low by most specialties but received the highest scores by anaesthesiology and ENT. Anaesthesiologists need good auditory discrimination and selective attention when monitoring anaesthetized patients [49]. For ENT-specialists, visual imagination and range of field vision are required to work in complex and narrow three dimensional spaces. These specialty-specific skills can be trained with mannequins [50] or in virtual reality simulations [51].

The identified competence profiles could provide a guideline for medical graduates of what to expect in their favoured medical specialty. Based on our survey, three main recommendations can be given to medical graduates who wish to choose a specialty for their postgraduate training. The most important aspect is to identify their individual intrinsic motivation for a specific specialty. Hence, medical graduates should explore their curiosity, the main intrinsic motivation of learning, with respect to a specialty of their choice, and their selfefficacy, the primary factor of learning motivation, which have been shown to influence each other [52]. A second decision could be whether graduates are interested in a specialty that specifically requires rather psychomotor or psychosocial skills. Psychomotor skills are prominently needed by all specialties who perform surgical procedures. This supposedly still reflects the development of the surgical specialties from the handicraft of barbers to surgery as a science [53] with a main focus lying on manual skills. Psychosocial skills are highly required by the different specialties belonging to the so called "talking medicine" [54]. Once this decision is made, the third aspect of specialty selection should be on specific requirements like mental or sensory abilities.

Our study has several limitations. As a pilot study, it was limited to one country and the invitation to participate was provided via an analogue physicians' journal distributed in one area of Germany and available in the internet. Therefore, we are not able to provide a response rate. Furthermore, part of the survey period coincided with the shutdown due to the COVID-19 pandemic which might additionally have hampered the 
response to the questionnaire. However, we received enough responses to analyse 17 of 19 participating specialties. Additionally, the Cronbach's alphas for four areas of competence are good except for "Psychomotor and multitasking abilities" and "Motivation", which include only two and five items, respectively. Another limitation is that we did not collect the age of the participants, which could play a role, since some medical specialties changed over time and, e.g. radiologists do very different things than a generation ago. This pilot study enabled us to provide a first insight into competence profiles of different specialties. Studies with a larger number of participants within each specialty or even subspecialty and including the age of the participants are needed to consolidate our pilot findings. These first insights into competence profiles might already serve as an initial decision aid for medical graduates what to expect form a certain specialty for postgraduate training. Investigating medical students' competence profiles and matching them with the profile of their desired specialty for postgraduate education would be an interesting next step.

\section{Conclusions}

Different competence profiles for medical specialities were discovered in this pilot study. The competence area "Motivation" reached the highest rank in almost all specialties. Additionally, many specialties either ranked "Psychomotor and multitasking abilities" or "Social interactive competences" and "Personality traits" highly. These findings could provide a first insight into specific competences required by medical specialties and support medical graduates in making their choices for a specialty for postgraduate training.

\section{Abbreviations \\ ANOVA: Analysis of variance; COVID-19: Corona Virus Disease 2019; ENT: ears, nose, throat; F-JAS: Fleishman job analysis survey; NRMP: National resident matching program; LSD: Least significant difference test; R- \\ Track: requirement-tracking; SPSS: Statistical package for the social sciences}

\section{Acknowledgements}

We would like to thank all physicians who participated in this study.

\section{Authors' contributions}

EZ and SH designed and performed the study. VO designed the questionnaire. SH recruited the participants and EZ coordinated the study and the data acquisition. VO performed the statistical analyses together with EZ and interpreted the results with SH. EZ and SH drafted the manuscript. All authors read and approved the final manuscript.

\section{Funding}

Open Access funding enabled and organized by Projekt DEAL.

\section{Availability of data and materials}

All data and materials are available from the manuscript and from the corresponding author upon request.

\section{Ethics approval and consent to participate}

The study was performed in accordance with the Declaration of Helsinki and the Ethics Committee of the Chamber of Physicians, Hamburg, confirmed the innocuousness of the study with consented, anonymized, and voluntary participation (PV3649). All participants provided informed written consent for participation in this study.

\section{Consent for publication}

Not applicable.

\section{Competing interests}

SH has a position as Section Editor to BMC Medical Education. EZ and VO have no competing interests.

\section{Author details}

${ }^{1}$ III. Department of Internal Medicine, University Medical Center Hamburg-Eppendorf, Martinistr. 52, D-20246 Hamburg, Germany. ${ }^{2}$ German Aerospace Center (DLR), Hamburg, Germany.

Received: 15 September 2020 Accepted: 9 November 2020

Published online: 12 January 2021

\section{References}

1 Borges NJ, Savickas ML. Personality and medical specialty choice: a literature review and integration. J Career Assess. 2002;10:362.

2. Petrides KV, McManus IC. Mapping medical careers: questionnaire assessment of career preferences in medical school applicants and final-year students. BMC Med Educ. 2004;4:18.

3. Xu R. A differentiation diagnosis - specialization and the medical student. N Engl J Med. 2011;365:391-3.

4. Lachish S, Goldacre MJ, Lambert TW. Views of UK doctors in training on the timing of choosing a clinical specialty: quantitative and qualitative analysis of surveys 3 years after graduation. Postgrad Med J. 2018;94:621-6.

5. Birck S, Gedrose B, Robra BP, Schmidt A, Schultz JH, Stosch C, et al. Stability of long-term professional objectives of young physicians during postgraduate training. Results of a multicenter cohort study. Dtsch Med Wochenschr. 2014;139:2173-7 [Article in German].

6. Weissman C, Tandeter H, Zisk-Rony R, Weiss YG, Elchala U, Avidan A, et al. Israeli medical students' perceptions of six key medical specialties. Isr J Health Policy Res. 2013;2:19.

7. Baber S, Brettell R, Perera-Salazar R, Geenhalgh T, Harrington R. UK medical students' attitudes towards their future careers and general practice: a cross-sectional survey and qualitative analysis of an Oxford cohort. BMC Med Educ. 2018;18:160.

8. Phillips JR, Dodoo R, Petterson M, Xierali S, Bazemore I, Teevan A, et al. Specialty and geographic distribution of the physician workforce: what influences medical student \& resident choices? Robert Graham Center: AAFP Center for policy studies; 2009.

9. Van Way IIICW. Is there a surgeon shortage? Mo Med. 2010;107(5):309-12.

10. Mirvis DM. Choosing a medical specialty: the difference between what students want and what society needs. Isr J Health Policy Res. 2013;2:18.

11. Scott A, Joyce CM. The future of medical careers. Med J Aust. 2014;201(2): 82-3.

12. Pianosi K, Bethune C, Hurley K. Medical student career choice: a qualitative study of fourth- year medical students at Memorial University, Newfoundland. CMAJ Open. 2016;4(2):E147-52.

13. Reed VA, Jernstedt GC, Reber ES. Understanding and improving medical student specialty choice: a synthesis of the literature using decision theory as a referent. Teach Learn Med. 2001;13(2):117-29.

14. Weissman C, Schroeder J, Elchalal U, Weiss Y, Tandeter H, Zisk-Rony RY. Using marketing research concepts to investigate specialty selection by medical students. Med Educ. 2012;46:974-82.

15. Lefevre JH, Roupret M, Kerneis S, Karila L. Career choices of medical students: a national survey of 1780 students. Med Educ. 2010;44:603-12.

16. Sievert M, Zwir I, Cloninger KM, Lester N, Rozsa S, Cloninger CR. The influence of temperament and character profiles on specialty choice and well-being in medical residents. PeerJ. 2016:4:e2319.

17. Keating EM, O'Donnell EP, Starr SR. How we created a peer-designed specialty-specific selective for medical student career exploration. Med Teach. 2013;35:91-4. 
18. Patel K, Binder L, Desai BK, Goodwin F, Mattu A, Cheaito MA, et al. Designing the third- and fourth-year clerkship schedule. J Emerg Med. 2020; 58(3):e173-6.

19. Stahn B, Harendza S. Role models play the greatest role - a qualitative study on reasons for choosing postgraduate training at a university hospital. GMS Z Med Ausbild. 2014;31(4):Doc45.

20. Laurence C, Elliott T. When, what and how south Australian pre-registration junior medical officers' career choices are made. Med Educ. 2007:41:467-75.

21. Soethout MBM, Heymans MW, Ten Cate OJ. Career preference and medical students' biographical characteristics and academic achievement. Med Teach. 2008;30:e15-22

22. Cleland J, Johnston PW, French FH, Needham G. Associations between medical school and career preferences in year 1 medical students in Scotland. Med Educ. 2012;46:473-84.

23. Lambert EM, Holmboe ES. The relationship between specialty choice and gender of U.S. medical students, 1990-2003. Acad Med. 2005;80(9):797-802

24. Newton DA, Grayson MS, Thompson LF. The variable influence of lifestyle and income on medical students' career specialty choice: data from two U. S. medical schools, 1998-2004. Acad Med. 2005;80(9):809-14.

25. Dorsey ER, Jarjoura D, Rutecki GW. Influence of controllable lifestyle on recent trends in specialty choice by US medical students. JAMA. 2003: 290(9):1173-8

26. Veysman B. Physician, know thyself. BMJ. 2005;331(7531):1529.

27. Roth $A E$, Peranson E. The redesign of the matching market of American physicians: some engineering aspects of economic design. Am Econ Rev. 1999;89(4):749-80.

28. Nagarkar PA, Janis JE. Fixing the "match": how to play the game. J Grad Med Educ. 2012;4(2):142-7.

29. Freeman B. The ultimate guide to choosing a medical speciality. McGrawHill Medical: Lange medical book; 2004.

30. Oubaid, V. (Hrsg.). Der Faktor Mensch. Berlin: MWV-Verlag; 2019. [Book in German].

31. Fleishman EA, Reilly ME. Fleishman job analysis survey. Administrator guide. Potomac: MD Management Research Institute; 1995.

32. Kleinmann M, Manzey D, Schumacher S, Fleishman EA. F-JAS Fleishman Job Analyse System für eigenschaftsbezogene Anforderungsanalysen. Göttingen: Hogrefe; 2010. [Article in German].

33. Harendza S, Kim WC, Oubaid V. Anforderungsananlyse für Nephrologen in Klinik und Praxis. Der Nephrologe. 2019;14:159-63 [Article in German].

34. Bandura A. Self-efficacy: toward a unifying theory of behavioural change. Psychol Rev. 1977:84(2):191-215.

35. Smith F, Lambert TW, Goldacre MJ. Factors influencing junior doctors' choices of future specialty: trends over time and demographics based on results from UK national surveys. J R Soc Med. 2015;108(10):396-405.

36. Marshall DC, Salciccioli JD, Walton SJ, Pitkin J, Shalhoub J, Malietzis G. Medical student experience in surgery influences their career choices: a systematic review of the literature. J Surg Educ. 2015;72(3):438-45.

37. Seo HS, Eom HY, Kim MK, Kim YM, Song BJ, Son KY. A one-day surgical-skill training course for medical students' improved surgical skills and increased interest in surgery as a career. BMC Med Educ. 2017;17:265.

38. Hirayama R, Fujimoto Y, Umegaki M, Kagawa N, Kinoshita M, Hashimoto $\mathrm{N}$, et al. Training to acquire psychomotor skills for endoscopic endonasal surgery using a personal webcam trainer. J Neurosurg. 2013; 118:1120-6

39. Sato E, Mitani S, Nishio N, Kitani T, Sanada T, Ugumori T, et al. Development of proficiency-based knot-tying and suturing curriculum for otolaryngology residents: a pilot study. Auris Nasus Larynx. 2020;47(2):291-8.

40. Fischer JE. On the uniqueness of surgery. Am J Surg. 2005;189:259-63.

41. Charon R. The patient-physician relationship. Narrative medicine: a model for empathy, reflection, profession, and trust. JAMA. 2001;286(15): 1897-902.

42. Porcel JM, Casademont J, Conthe P, Pinilla B, Pujol R, García-Alegría J. Core competencies in internal medicine. Eur J Intern Med. 2012;23:338-41.

43. O'Riordan M, Dahinden A, Aktürk Z, Ortiz JMB, Dagdeviren N, Elwyn G, et al. Dealing with uncertainty in general practice: an essential skill for the general practitioner. Qual Prim Care. 2011;19:175-81.

44. Van Nimwegen KJM, Schieving JH, Willemsen MAAP, Veltman JA, van der Burg S, van der Wilt GJ, et al. The diagnostic pathway in complex paediatric neurology: a cost analysis. Eur J Paediatr Neuro. 2015;19:233-9.

45. Ross J, Watling C. Use of empathy in psychiatric practice: constructivist grounded theory study. BJ Psych Open. 2017;3:26-33.
46. Lukaszewicz A, Uricchio J, Gerasymchuk G. The art of the radiology report: practical and stylistic guidelines for perfecting the conveyance of imaging findings. Can Assoc Radiol J. 2016;67(4):318-21.

47. Lee B, Whitehead MT. Radiology reports: what you think you're saying and what they think you're saying. Curr Probl Diagn Radiol. 2017;46(3):186-95.

48. Modell H, Cliff W, Michael J, McFarland J, Wenderoth MP, Wright A. A physiologist's view of homeostasis. Adv Physiol Educ. 2015;39:259-66.

49. Dobson G, Chow L, Flexman A, Hurdle H, Kurrek M, Laflamme C, et al. Guidelines to the practice of anesthesia - revised edition 2019. Can J Anesth. 2019;66(1):75-108.

50. Bhalla S, Beequn I, Awad Z, Tolley N. Simulation-based ENT induction: validation of a novel mannequin training model. J Laryngol Otol. 2020; 134:74-80.

51. Dharmawardana N, Ruthenbeck G, Woods C, Elmiyeh B, Diment L, Ooi EH, et al. Validation of virtual-reality-based simulations for endoscopic sinus surgery. Clin Otolaryngol. 2015;40:569-79.

52. Li Y, Huo T, Zhuang K, Song L, Wang $X$, Ren Z, et al. Functional connectivity mediates the relationship between self-efficacy and curiosity. Neurosci Lett. 2019:711:1344442.

53. Himmelmann L. From barber to surgeon - the process of professionalization. Sven Med Tidskr. 2007;11(1):69-87 [Article in Swedish].

54. Goesmann C. What makes "talking medicine" successful: patience-attentionopenness. MMW Fortschr Med. 2011;153:24 [Article in German].

\section{Publisher's Note}

Springer Nature remains neutral with regard to jurisdictional claims in published maps and institutional affiliations.
Ready to submit your research? Choose BMC and benefit from:

- fast, convenient online submission

- thorough peer review by experienced researchers in your field

- rapid publication on acceptance

- support for research data, including large and complex data types

- gold Open Access which fosters wider collaboration and increased citations

- maximum visibility for your research: over 100M website views per year

At BMC, research is always in progress.

Learn more biomedcentral.com/submissions 